\title{
SEMANTIC-STRUCTURAL PECULIARITIES OF SHAKESPEAREAN NEOLOGISMS
}

\author{
Ismoilova Dilorom $\bowtie$; Fergana State University, Uzbekistan
}

\begin{abstract}
The article reveals the contributions of William Shakespeare to the development of the English language. Author discusses structural features of Shakespearean neologisms and highlights semantic differences in terms of periods of English language. The st udy reveals the peculiarities of Shakespearean neologisms due to the standpoints of methods of analysis. The article targeted to clarify the neologisms made in the realm of morphological word-formation. The author utilized the observation method and conduc ted the qualitative research. The neologisms by the dramatist are divided into 4 categories considering their ways of formation. They are following: the neologisms that were coined by affixation ; the neologisms that were minted by syntactic way ; originally new -born words; the neologisms that were coined by conversion.
\end{abstract}

Keywords: Neologism, Affixation, Morphological word $\quad$-formation, Conversion, Syntactic word-formation.

d.r.ismoilova@mail.ru

Citation: Dilorom, I. (2021). Semantic-structural peculiarities of shakespearean neologisms . Social Sciences, Humanities and Education Journal (SHE Journal) ，2(2), 78 - 82. DOI: $10.25273 /$ she.v2i2.9227

\section{$(\mathrm{oc})$ EY-NC-SA}

Published by Universitas PGRI Madiun. This work is licensed under the Creative Commons AttributionNonCommercial-ShareAlike 4.0 International License. 


\section{INTRODUCTION}

The quintessential playwright and talented poet William Shakespeare contributed to the development of the English language substantially. His writing style, grammar structure in the works as well as vocabulary is considered as a basement for Standard English. Admittedly, in the juncture of his influence on English language, neologisms- coined by Shakespeare are the main sources of enrichment of the English language. That was not simple coinage certainly. His coined words are so expressive and colourful in meaning which generated them to pass from time to time. Interestingly, how did he bring the new words into language? What kind of peculiarities do we differentiate from other writers?

Initially, his neologisms consist of two independent words which are combined together and form compound words. Besides, the writer coined the words adding suffixes and prefixes. Converting nouns into verbs and changing verbs into adjectives can be noted as a fruitful way of creating new words.

\section{MATERIAL AND METHODS}

The primary data source is "A dictionary of English language" compiled in 1878 by Samuel Johnson. In order to state the findings, author used" The Complete Works of Shakespeare". In order to reference the study data, the researcher mentions Act, Scene and the name of the character.

What is noteworthy that, his minted words were so expressive and meaningful. As a consequence, they were easily absorbed in the English lexicon and become most frequently used lexicon.

Their common nature can be demonstrated as the crucial reason for their quick acceptance by common people. People understood them without difficulties and then used in daily speech and caused the popularization of his works too. The opinions abovementioned were proved by the Shakespearean scholars Charles and Mary Cavden Clark: "Shakespeare wrote in a royal style as he was "king of the poets". He created powerful works and coined the essential words. Everybody digested them well, because his words were so colourful and sensitive certainly. So those words were used so often in oral speech."

\section{RESULT AND DISCUSSION}

In the meantime we scrutinized the neologisms, we assured that, majority of them were coined by affixation. Affixation is based on adding prefixes and suffixes to the stem of the word. Like other neologisms coined Shakespeare in different ways, those neologisms were quoted in "The dictionary of English language" by Samuel Johnson. We would like to analyse some features of forming those words.

One of the productive suffix among many others is -tion and by the means of this suffix Shakespeare coined majority of nouns. In Elizabethan Era, the verb form of addict was known to the people. The great innovator created its noun form which is frequently utilized in both written and oral speech in Modern English too.

It is Othello's pleasure, our noble and valiant general, that upon certain tidings now arrived, importing the mere perdition of the Turkish fleet, every man put himself into triumph; some dance, some tomake bonfires, each man to what sport and reveal his addiction leads him;

(Act II, Scene II, King Henry the fifth, Herald)

Since his addiction was to courses vain,

His hours fill'd up with riots, banquets, sports; 
(Act I, Scene I, King Henry the fifth, Canterbury)

The coinage of the word rumination had undergone similar way of word-formation.

I have neither the scholar's melancholy, which is emulation; nor the musician's, which is fantastical; nor the courtier's which proud; nor the

Soldier's, which is ambitious; but it is melancholy of my own, compounded of many simples, extracted from many objects, indeed, the sundry contemplation of my travels; in which my often rumination wraps mein a most humorous sadness.

(Act IV, Scene I, As you like it, Rosalind)

Another neologism made by the affix abovementioned is accomodation. Even most of the native speakers do not know the origina dn the author of the word. We can read the word in the tragedy of "Othello" via the speech of main character:

With such accomodation and besort

As levels with her breeding. (Act I, Scene III, Othello, Othello)

The words made with the suffix ment are still utilized in common sppech and seem to be belong to the contemporary English. In fact, they are results of Shakespaere's creativity. Amazement can be comon example of this type of word-formation and it is observed in his legacy. The expressiveness of the word depends on the context and the other parts of sentences respectively.

They did so, to the amazement of mine eyes

That look'd upon't.

(Act II, Scene IV, Macbeth, Roth)
Put not yourself into amazement how these things should be: all difficulties are but easy when they are known.

(Act IV, Scene I, Measure for Measure, Duke)

Moreover, this neologism was used in different phrases and served to express the feelings of the characters respectively:

"Amazement on thy mother sits", "wild amazement hurries up and down", "all this amazement can I qualify", "no more amazement", " I flame'd amazement", "wonder and amazement", "will strike amazement", "behold distraction, frenzy and amazement".

To analyze the semantic-structural feature of the word investment generates the semantic meaning of the word in terms of time factors. That is why, the original meaning of the word was' to cover", "To block" and "To conceal" at that time. Currently, it denotes money used in a way that may earn you more money.

Do not believe his vows; for they are brokers,

Not of that dye which their investments show.

(Act I, Scene III, Hamlet, Polonius)

It is known that, the word excitement is listed among frequentlyused vocabulary. This is also coined by the talented writer by the help of affixation.

Excitements of my reason and my blood,

And let all sleep, while to my shame I see.

(Act IV, Scene IIV, Hamlet, Hamlet)

One can observe varying neologisms with the suffix -less more than enough. -less convey the meaning of non-existence of something. Baseless is an example of the coinage which 
conserve own original meaning despite of time factors.

And like the baseless fabric of the vision,

The cloud capp'd towers , the gorgeous palaces.

(Act IV, Scene I, The Tempest, Prospero)

Clearly, the suffix is added to the noun and as a result an adjective appears. Noiseless is a good example of expressive neologisms used as a part of a metaphor of Shakespeare.

Th' inaudible and noiseless foot of time,

Steals ere we can effect them.

(Act V, Scene 3, All is well, that ends well, King)

In the tragedy of "Macbeth" the word assassination was used in the speech of the main character Macbeth.

If it were done when 'tis done, then 'twere well

It were done quickly, If the assassination

Could trammel up the consequence, and catch;

(Act I, Scene VII, Macbeth, Macbeth)

Shakespearean coinage restoration denoted the political events at the period of the writer and it was hint for returning of the King Charles II and monarchy. Naturally, it has different meaning at current time.

Oh my dear father, restoration hang

Thy medicine on my lips, and let this kiss.

(Act II, Scene VII, Cordelia, King lear)

According to the definition in Macmillan Dictionary, the word denotes "the act of returning of hidden, robbed objects", "the act of installation old programme of repaired computer" and others.

The majority of stylistic colourful neologisms were made up with the suffix -y admittedly. Shakespeare coined so many adjectives by the hlp of it. The word bloody can respond to descriptions abovementioned.

A most harsh one, and not to be understood without bloody succeeding. My master!

(Act II, Scene III , Parolless, All is well that ends well)

Interestingly, the dramatist utilized the word under its denotational (dictionary) meaning in many comedies and tragedies: bloody napkins, bloody teeth,bloody pillow, bloody handkerchief, bloody hands, bloody cloth.

Furthermore, the writer used it with connotational (figurative) meaning too: bloody brother, bloody deeds, bloody tyranny, bloody thoughts, bloody battles, bloody acts, bloody day, bloody youth, bloody book, bloody times.

In the juncture of figurative meaning of neologisms, we can state the word gloomy:

Forc'd in the ruthless, vast, and gloomy woods?

(Act IV, Scene I, Titus, The tragedy of Titus Andronicus)

But darkness and the gloomy shade of death

Envron you, till mischief and despair.

(Act V, Scene IV, Pucelle, King Henry VI)

We can give numerous examples for this type of word-formation in terms of neologisms by Shakespeare which were quoted to Shakespeare in "The dictionary of English language" by Samuel Johnson: 
palmy, majestic, generous, suspicious, impartial, , critical, lonely and so on.

However, some words can not be found in that dictionary( The dictionary was published in 1878), they are quoted to Shakespeare proudly: manager, fashionable, marketable, laughable and others.

All things considered, William Shakespeare was the quintessential writer in the period of Renaissance. He contributed to the development of the English language and literature as well as he had own influential role in the development of English speech culture. As humankind uses his words, reads his works and keep quoting Shakespeare in their daily speech knowingly and sometimes unknowingly - Shakespeare never dies.

Despite the fact that, at least one article is written devoted to the legacy of him, many secrets have not been revealed yet. Because his contribution is like an ocean, one is able to discover own findings.

\section{REFERENCES}

V. King, (2006) Purley Language School, Facebook page

D. Crystal, (2014) The World in words, podcast, July 23

H. Bloom, (1999)The invention of the Human, Berkley Publishing

S. Johnson. (1878)A dictionary of the English language, Heidelberg
Ch. Clarke, The Shakespeare Key, Rivington, 1878

Complete works of W. Shakespeare, 1990-1993, The World library.

F. Rahman, S.Wed, (2019)Linguistic deviation and the rhetoric figures in Shakespeare's selected plays. XLinguae, Volume 12 Issue 1, January

Vickers, Brian, (2007)Shakespeare. A Lover's complaint, Cambridge University press

Larer, Seth, (2007) Inventing English:a portable history of the language,Columbia University press

H. Craig, (2011) Shakespeare's Vocabulary:Myth and Reality, Shakespeare Quarterly, vol 62, No 1

V. George, (2014)Translating and editing Shakespeare today, Linguistic and philosophical investigations, Woodside

Watson, N. Robert,( 2009) Coining Words on the Elizabethan and Jacobean stage, Philolological Quarterly.

John son, Keith London, (2013 )Shakespeare's English: A practical Linguistic guide.

G. Bryan, (1982) Shakespeare's Latinate Neologisms, Shakespeare's study, New York. 